\title{
The progress in research and application of entomophagous insects in Integrated Pest Management (IPM)
}

\author{
Postępy w badaniach i wykorzystanie entomofagów \\ w integrowanej ochronie roślin
}

\author{
Stefan Pruszyński
}

\begin{abstract}
Summary
The use of entomophagous insects with the application of selective pesticides gave rise to the development of the concept of integrated pest management and it is still considered as on of the most permanent and important elements of currents integrated plant protection programmes. Most research on the species composition of entomophagous and their role in the control of local entomofauna, together with an introduction and mass rearing was done in Poland in the second half of the twentieth century, the years 1960-1990. Their result gave the base for development of biological and integrated pest management in greenhouse crops against pests, as well as the introduction of the integration elements to the protection of orchards. Proper and optimal usage of entomophagous insects requires a significant intensification of research, enrichment of the environment resistance through the creation of ecological grounds and the improvement of agricultural advisers and agricultural producers knowledge.
\end{abstract}

Key words: entomophagous insects, introduction, mass rearing and release, natural regulation

\section{Streszczenie}

Wykorzystanie entomofagów w połączeniu z zastosowaniem selektywnych pestycydów dało początek koncepcji integrowanej ochrony roślin i pozostaje nadal trwałym i ważnym elementem obecnych programów ochrony roślin. Największe nasilenie badań nad składem gatunkowym i znaczeniem miejscowej entomofauny, a także introdukcją i ich masową hodowlą miało miejsce w Polsce, w drugiej połowie 20. wieku, lata 1960-1990, a ich wynikiem było stworzenie podstaw i upowszechnienie biologicznej i integrowanej ochrony upraw szklarniowych przed szkodnikami, a także wprowadzenie elementów integracji do ochrony sadów. Prawidłowe i optymalne wykorzystanie roli entomofagów będzie wymagać znacznej intensyfikacji badań, wzbogacenia oporu środowiska poprzez tworzenie użytków ekologicznych oraz podniesienia wiedzy doradców rolniczych i samych producentów rolnych.

Słowa kluczowe: entomofagi, introdukcja, masowa hodowla i uwalnianie, naturalna regulacja

Emerytowany Profesor IOR - PIB

Instytut Ochrony Roślin - Państwowego Instytutu Badawczego

Władysława Węgorka 20, 60-318 Poznań

s.pruszynski@iorpib.poznan.pl 


\section{Wstęp / Introduction}

Zjawisko drapieżnictwa i pasożytnictwa owadów zostało wcześnie zauważone i było wielokrotnie wykorzystywane $\mathrm{w}$ ochronie roślin. Wydaje się przy tym, że nawet przy braku zrozumienia zachodzących w naturze procesów nasi przodkowie podświadomie wyczuwali pożyteczną działalność entomofagów, a przykładem mogą tu być cieszące się od wieków wielką sympatią oraz poszanowaniem biedronki.

Wcześnie też podejmowano próby ich wykorzystania w ograniczaniu liczebności zawleczonych szkodników, ale także w zwalczaniu występujących na uprawach mszyc.

Według Portčinskiego (1912) w Kalifornii, w USA wykorzystując gromadzenie się biedronek na zimowanie zbierano w czasie zimy do $40 \mathrm{mln}$ chrząszczy biedronek, przechowywano je w chłodnych insektariach i wiosną rozwożono na uprawy zaatakowane przez mszyce.

Również idea integracji zrodziła się przy opracowywaniu programu ochrony lucerny przed mszycami Acertosiphon pisum Harr. i Tetrioaphis maculata Buck uwzględniających wykorzystanie biedronki Hippdammia convergens Guer. i selektywnych środków ochrony roślin (Stern i wsp. 1959).

W krótkim okresie czasu wykorzystanie entomofagów, a więc pasożytów i drapieżców stało się jednym z najważniejszych elementów opracowywanych programów integrowanej ochrony, a w realizacji tego wykorzystania wypracowano kilka metod.

\section{Introdukcja entomo- i akarofagów Introduction of entomo- and acarophages}

W roku 1889 przewieziono w ślad za zwalczonym wcześniej czerwcem Icerya purchasi (Mask.) z Australii do USA biedronkę Rodolia cardinalis (Muls.) z celem ograniczenia występowania tego szkodnika i była to pierwsza udokumentowana i jednocześnie bardzo udana introdukcja owada pożytecznego (Pruszyński 1989). Rozwój wymiany towarowej szybko doprowadził do niezamierzonego przewożenia na nowe tereny szkodników, które tam wcześniej nie występowały i które zaczęły stanowić istotne zagrożenie dla miejscowych upraw. Introdukcja stała się na przełomie 19. i 20. wieku bardzo szeroko wykorzystywaną metodą, a na całym świecie trwały poszukiwania skutecznych pasożytów i drapieżców mogących znaleźć zastosowanie w ograniczaniu liczebności zawleczonych szkodników. Był to w tym okresie jeden z najbardziej skutecznych sposobów wykorzystania w ochronie roślin metody biologicznej.

$\mathrm{Z}$ biegiem lat introdukcją objęto nie tylko gatunki atakujące szkodniki zawleczone, ale także podjęto próby sprowadzenia entomofagów z myślą o wzbogaceniu naturalnego oporu środowiska.

Jakkolwiek Polska nie należy do krajów przodujących w introdukowaniu entomofagów to odnotować należy wiele podejmowanych prób, z których część była bardzo udana (Pruszyński 1989; Wiąckowski 2006).

W latach 30. ubiegłego wieku introdukowano do Polski pasożyta ośca korówkowego (Aphelinus mali Hald.) celem zwalczania zawleczonej wcześniej do Polski bawełnicy korówki (Eriosoma lanigerum Hausm.). Introdukcja była bardzo udana, pasożyt skutecznie likwidował bawełnicę i występuje na terenie naszego kraju do chwili obecnej, przewożony jedynie na tereny, na których po zlikwidowaniu mszycy jego populacja uległa rozproszeniu.

Po II wojnie światowej, po nalocie na nasz kraj stonki ziemniaczanej podjęto próbę introdukcji z Ameryki Północnej jej wrogów naturalnych, a w tej liczbie drapieżnych pluskwiaków Perillus bioculatus Fabr. i Podisus maculiventris Say. oraz pasożyta Doryphorophaga doryphorae (Riley), jednakże nie udało się zaaklimatyzować tych gatunków w Polsce. Jednorazowo w ramach międzynarodowego programu badawczego introdukowano pasożyta jaj stonki ziemniaczanej gatunek Edovum puttleri (Lipa i wsp. 1998).

Z myślą o wzbogaceniu środowiska naturalnego sprowadzono do Polski kilka gatunków wrogów naturalnych mszyc: Aphidius smithi S., Lysiphlebus testaceipes Cres., Aphidius colemani oraz Hippodamia convergens Guer. Brak jest jednak danych o występowaniu tych gatunków w warunkach naturalnych Polski oraz roli, jaką moga spełniać w ograniczeniu liczebności mszyc. Niezamierzoną introdukcją byłą migracja do Polski biedronki azjatyckiej Harmonia axyridis Pallas. Gatunek ten sprowadzony do kilku krajów europejskich ,wymknął się” spod kontroli przelatując na inne tereny i wzbudzając swym zachowaniem, gromadzeniem się w pobliżu domostw, niepokój mieszkańców (Pruszyński i Fiedler 2009). Biedronka ta występuje obecnie prawdopodobnie już na terenie całego kraju, jednak brak jest danych co do znaczenia jej działalności w ograniczaniu mszyc, względnie jej wpływu na inne elementy środowiska.

Do bardzo udanych należy zaliczyć sprowadzenie do Polski wrogów naturalnych szkodników szklarniowych: pasożyta mączlika szklarniowego (Encarsia formosa Gah.) oraz drapieżnego roztocza żerującego na przędziorkach Phytoseiulus persimilis A.- H. Przeprowadzone badania, a także introdukcja kolejnych gatunków mogących znaleźć zastosowanie w biologicznym zwalczaniu szkodników szklarniowych m.in.: Amblyseius mckenziei Sch. Et Pr. wroga naturalnego wciornastków i Macrolophus costalis Fieb. - ograniczającego liczebność mączlika doprowadziły do opracowania stosowanej dziś powszechnie biologicznej i integrowanej ochrony upraw szklarniowych.

Do udanych należy zaliczyć dokonaną przez Instytut Sadownictwa i Kwiaciarstwa w Skierniewicach (obecnie Instytut Ogrodnictwa) introdukcję drapieżnego roztocza Typhlodromus pyri Oud. celem jego wykorzystania w ograniczaniu przędziorków w sadach. Drapieżcę tego po wyhodowaniu populacji odpornej na niektóre insektycydy stosuje się w wielu sadach towarowych w Polsce.

$\mathrm{Z}$ innych udanych prób wymienić należy introdukcje biedronki Cryptolaemus montrouzieri (Muls.) z celem zwalczania wełnowców, drapieżnego roztocza Typhlodromus (Metaseiulus) occidentalis Nesbitt - wroga naturalnego przędziorków, pasożyta Itoplectis conquisitor (Say.) ograniczającego liczebność niektórych szkodników w lasach, kilku gatunków pasożytów wyłogówki jedlineczki oraz różnych gatunków kruszynka m.in. Trichogramma semblidis Aut. i T. achaceae N. et N. (Wiąckowska 1987). 
Uwarunkowania introdukcji entomofagów oraz szczegółowe wykazy sprowadzonych gatunków przedstawili szerzej Pruszyński (1989) i Wiąckowski (2006).

\section{Hodowla i masowe uwalnianie entomofagów Mass rearing and release of entomophages}

Ten sposób wykorzystania drapieżców i pasożytów szkodników osiagnął w ostatnim półwieczu bardzo poważny postęp i wiele niekwestionowanych sukcesów.

$\mathrm{Na}$ pierwszy plan wybija się tu stosowanie owadów pożytecznych w ochronie przed szkodnikami upraw pod osłonami. Zapoczątkowane w latach 70. ubiegłego wieku badania i praktyczne zastosowanie w biologicznym zwalczaniu przędziorków drapieżcy $P$. persimilis oraz w zwalczaniu mączlika szklarniowego pasożyta $E$. formosa dały początek opracowaniu programu zwalczania szkodników szklarniowych obejmującego praktycznie wszystkie gatunki szkodników oraz zapylanie roślin.

Polska miała istotny udział w badaniu i wdrażaniu tego systemu, a jako niekorzystne zjawisko jakie miało miejsce w Polsce należy wymienić likwidację na początku lat 90. prowadzonych w Polsce masowych hodowli stosowanych w szklarniach entomofagów i całkowite oparcie biologicznej ochrony w szklarniach o drapieżce i pasożyty sprowadzane z zagranicznych hodowli.

Gatunkami, których hodowlę i stosowanie wykorzystuje się w praktyce ochrony roślin są pasożyty jaj owadzich z rodzaju kruszynek (Trichogramma spp.). Filippov (1989) podał, że w roku 1987, 5 gatunków Trichogramma było hodowanych w ZSRR, w 600 wyspecjalizowanych biolaboratoriach i były one stosowane w zwalczaniu szkodników upraw rolniczych i ogrodniczych na areale $15 \mathrm{mln}$ ha.

W ograniczaniu liczebności słonecznicy orężówki (Heliothis armigera Hubner) na powierzchni ponad $1 \mathrm{mln}$ ha stosowano hodowanego $\mathrm{w}$ biolaboratoriach pasożyta Habrobracon hebetor Say. To zastosowanie entomofagów autor dodatkowo uzupełnia danymi o hodowli i uwalnianiu m.in. biedronki $R$. cardinalis, pasożyta Aphelinus mali Hald oraz pluskwiaków P. maculiventris Say. i P. bioculatus Fabr. W zwalczaniu stonki ziemniaczanej na powierzchni 50-100 tys. ha.

W roku 1996 zgodnie z informacją uzyskaną od Prof. dr A. Smetnika (Pruszyński 1997), po zmianie systemu politycznego, gospodarczego i administracyjnego w Rosyjskiej Federacji funkcjonowało już tylko 271 biolaboratoriów, które hodowały 18 gatunków pasożytów i drapieżców w liczbie ogólnej około 12,3 mln osobników oraz $427 \mathrm{~kg}$ jaj spasożytowanych przez kruszynka. W tym czasie kruszynka stosowano na Białorusi na powierzchni około 50 tys. ha. W Bułgarii, w 21 biolaboratoriach hodowano kruszynka stosowanego na 100 tys. ha upraw ogrodniczych i rolniczych oraz 60 tys. ha lasów, a w Rumunii pasożyta uwalniano na około 300 ha winnic. Dodatkowo w wymienionych krajach powszechnie hodowano i stosowano entomofagi w szklarniach, np. w Bułgarii 5 gatunków drapieżców i pasożytów uwalniano na powierzchni około 700 ha szklarni.
W Polsce szerokie badania nad możliwością hodowli i wykorzystania kruszynka $\mathrm{w}$ polskiej ochronie roślin prowadzono w latach 60. i 70. ubiegłego wieku głównie w Instytucie Sadownictwa i Kwiaciarstwa w Skierniewicach, w Instytucie Ekologii Polskiej Akademii Naukowej w Dziekanowie Leśnym, Instytucie Ochrony Roślin w Poznaniu, Akademii Rolniczej w Poznaniu oraz w latach późniejszych w Katedrze Ekologii i Ochrony Środowiska Akademii Świętokrzyskiej w Kielcach (Kadłubowski 1957, 1973; Kot 1959, 1962; Wiąckowski i wsp. 1963; Górski 1973; Niemczyk i Bąkowski 1973; Wiąckowska 1987).

W warunkach klimatycznych Polski oraz przy wysokich wymaganiach co do jakości produktów i dostępności skutecznych środków ochrony roślin w tym biologicznych, kruszynek nie znalazł szerszego zastosowania i nie podejmowano jego masowej hodowli.

Ciekawym powrotem do wykorzystania kruszynka sa badania prowadzone w Terenowej Stacji Doświadczalnej Instytutu Ochrony Roślin - Państwowego Instytutu Badawczego w Rzeszowie i Uniwersytecie Przyrodniczym we Wrocławiu nad ograniczaniem przez tego pasożyta populacji omacnicy prosowianki (Ostrinia nubilalis) w uprawach kukurydzy (Lisowicz i Kot 1999; Bereś i Lisowicz 2005; Żołnierz i Hurej 2005; Bereś 2008).

Z przeprowadzonych w latach 1996-2004 badaniach przy uwalnianiu kruszynka gatunków T. evanesceus, T. embryophagum i T. pintoi (w latach 1996 i 1997 pasożyta uzyskano $\mathrm{z}$ hodowli prowadzonej $\mathrm{w}$ Instytucie Ekologii Polskiej Akademii Nauk w Dziekanowie Leśnym, natomiast $\mathrm{w}$ pozostałych latach był to biopreparat o nazwie Trichoplus zakupywany w Czechach) w liczbie 150 do 200 tys. pasożytów na ha uzyskano ograniczenie uszkodzeń kolb i złamanych roślin kukurydzy od około 40 do ponad $60 \%$. Przyczyną odnotowanej niższej czy nawet braku skuteczności była według autorów zła jakość otrzymanego kruszynka, względnie niedostosowanie gatunków pasożyta do żywiciela.

Bereś (2008) we wnioskach wynikających z badań sugeruje przydatność tej metody dla rolnictwa ekologicznego, a także potrzebę zwiększenia normy uwalnianego pasożyta oraz zbadanie przydatności innych gatunków kruszynka.

W światowym wykorzystaniu tego pasożyta za niewątpliwe osiągnięcie, obok modyfikacji i upowszechnieniu masowej hodowli należy uznać wyodrębnienie gatunków kruszynka o zwiększonym powinowactwie w odniesieniu do poszczególnych gatunków szkodników. Bardzo wyraźnie zwiększyło to skuteczność kruszynka i w profesjonalnym rozmnażaniu utrzymywana jest hodowla kilku gatunków tego pasożyta.

Osiagnięciem natomiast pracowników Instytutu Sadownictwa i Kwiaciarstwa w Skierniewicach (obecnie Instytut Ogrodnictwa) była introdukcja i uzyskanie odpornych na chemiczne środki ochrony roślin populacji drapieżnego roztocza $T$. pyri. Po opracowaniu masowej hodowli gatunek ten jest wprowadzany do sadów, w których skutecznie ogranicza liczebność roztoczy roślinożernych, głownie przędziorków. Ten sam zespół opracował masową hodowlę biedronki, skulika przędziorkowca (Stethorus punctillum) również wroga naturalnego 
przędziorków, co znacznie zwiększy możliwość biologicznego ograniczania przędziorków w sadach.

\section{Wykorzystanie naturalnej regulacji liczebności szkodników / Natural reduction of pests}

Wykorzystanie naturalnej redukcji liczebności szkodników, jaka ma miejsce w środowisku naturalnym było od początku traktowane jako najważniejszy i podstawowy element integrowanych programów ochrony roślin. Potwierdzenie tego znajdujemy nie tylko w definicjach integrowanej ochrony roślin, w których „Integrowana ochrona roślin jest opartą na podstawach ekologicznych strategią zwalczania organizmów szkodliwych, która silnie podkreśla wykorzystanie naturalnych czynników śmiertelności agrofagów, takich jak wrogowie naturalni i czynniki klimatyczne..." (Flint i van den Bosch 1981), ale także w Załączniku nr 3 do Dyrektywy Parlamentu Europejskiego i Rady 2009/128/WE, w którym zaleca się podejmowanie wszelkich działań, $\mathrm{w}$ tym agrotechnicznych, hodowlanych, w celu niedopuszczenia do rozwoju agrofagów oraz tworzenie warunków do rozwoju i ochronę organizmów pożytecznych.

Zrozumiałym w tej sytuacji jest dynamiczny rozwój badań nad możliwością wykorzystania w programach integrowanych entomofauny pożytecznej. Badania te obejmowały poznanie składu gatunkowego wrogów naturalnych poszczególnych szkodników, wytypowanie gatunków najważniejszych, określenie ich znaczenia w ograniczaniu liczebności szkodnika, określenie selektywności chemicznych środków ochrony roślin dla owadów pożytecznych, ustalenie terminów zabiegów i końcowe opracowanie integrowanego programu ochrony.

Bardzo ważnymi elementami tych programów było opracowanie metod rejestracji i sygnalizacji pojawu agrofagów oraz ustalenie wartości progów szkodliwości, a więc liczebności szkodnika, przy której należy podjąć zwalczanie chemiczne. Koncepcje progów szkodliwości rozwinęli Samersow i Triepaszko (1999) wprowadzając pojęcie progów ekologiczno-ekonomicznych. Według tych autorów decyzję o podjęciu chemicznego zwalczania należy podejmować nie tylko na podstawie liczebności czy nasileniu agrofaga, ale uwzględniając także zdrowotność populacji agrofaga, obecność wrogów naturalnych, cechy chronionej odmiany oraz wpływ spodziewanych warunków klimatycznych na rozwój szkodnika i jego wrogów naturalnych. Dopiero znajomość tych wszystkich elementów pozwala na podjęcie decyzji o zabiegu.

Polska nauka aktywnie uczestniczyła w badaniach nad opracowaniem integrowanych programów ochrony roślin, a zasięg prowadzonych prac szerzej omówili Pruszyński i wsp. (2012).

Przykładem podejścia do integrowanej ochrony przed szkodnikami jest praca Pałosza i wsp. (1994) dotyczaca podstaw integrowanej ochrony rzepaku ozimego. W swej pracy autorzy uwzględnili wykorzystanie naturalnych elementów ekosystemu, wyniki badań nad entomofauną pożyteczną, wykorzystanie w ograniczaniu chowacza podobnika pasożyta Trichomalus perfectum Walk. oraz racjonalne, dostosowane do pojawu pasożyta stosowanie agrochemikaliów.

Niestety kolejne lata nie przyniosły postępu w badaniach i wdrożeniu integrowanych programów ochrony i nie nastapił spodziewany i oczekiwany rozwój integrowanej ochrony, a wiele powodów niepowodzeń podał Dąbrowski (2000).

Nie nastąpił również rozwój metody biologicznej (Lipa i Pruszyński 2010), której zakres stosowania w skali światowej nie osiaga 5\% ogólnego chronionego areału. Nadal zbyt mało jest prac, w których określano by udział drapieżców i pasożytów w regulacji liczebności szkodników (Olszak 2005, 2010) oraz brak jest zaleceń określających warunki, w jakich należy odstępować od wykonania zabiegu. Ten brak postępu widoczny jest w publikowanych obecnie programach integrowanych ochrony upraw rolniczych, w których udział metody biologicznej jest ograniczony do kilku zdań oraz ogólnego opisu ochrony entomofauny pożytecznej (Korbas i Mrówczyński 2011), a także w metodykach integrowanej produkcji (Pruszyński 2007).

Ciekawym, ważnym i rozwijającym się obecnie kierunkiem badań są prace nad racjonalnym pozostawianiem tzw. użytków ekologicznych, doborem wysiewanych w nich roślin oraz znaczeniem tych terenów dla wzbogacenia liczebności entomofagów, w tej liczbie zapylaczy (Twardowski i wsp. 2009; Wiech i wsp. 2009; Dąbrowski 2010). Realizacja tych badań powinna stanowić podstawę do powrotu, do obserwacji nad znaczeniem entomofagów $\mathrm{w}$ ograniczaniu nasilenia występowania organizmów szkodliwych i umiejętnego wykorzystania ich roli w tworzeniu integrowanych programów ochrony roślin.

\section{Podsumowanie / Summation}

Po okresie intensywnych badań nad wykorzystaniem wrogów naturalnych w ograniczaniu liczebności i zwalczaniu szkodników roślin uprawnych na świecie i w Polsce, w latach 60. do 90. XX wieku nastapiło obecnie widoczne spowolnienie tych prac i ich ograniczenie. Tendencja ta ma miejsce pomimo silnego nacisku na ograniczanie stosowania chemicznych środków ochrony roślin oraz znacznego wspierania rozwoju rolnictwa ekologicznego.

Przyczyn takiego stanu jest kilka. Pierwsza to chyba brak szerszego wdrożenia integrowanej ochrony upraw rolniczych. Wiele z przyczyn wpływających na taką sytuację omówił Dąbrowski (2000), ale podkreślić należy brak środków na badania, brak koordynacji badań, brak przygotowania doradców oraz producentów do realizacji integrowanej ochrony i wreszcie brak zachęt finansowych (dopłaty do środków biologicznych, promocja produktów, łatwiejszy dostęp do rynku) dla stosowania integrowanej ochrony. Pisząc o potrzebie zachęt pamiętać należy, że stosowanie integrowanej ochrony, a w tym owadów pożytecznych jest systemem bardziej skomplikowanym, wymagającym od producenta większego zaangażowania i często, np. poprzez stosowanie selektywnych środków droższe. 
Mając na uwadze dalszy rozwój ochrony roślin oparty o zasady integrowanej ochrony, która stanie się od 1.01.2014 roku obowiązującą, należy oczekiwać bardzo silnego wsparcia ze strony jednostek administracji rządowej i samorządowej dla podjęcia i realizacji koniecznych działań. Należy do nich zaliczyć edukację i szkolenia, znaczny wzrost nakładów na badania oraz wprowadzenie zachęt finansowych dla producentów stosujących metodę biologiczną, a w niej wykorzystanie pożytecznej działalności entomofagów.

Integrowana ochrona stanie się obowiązkiem, co nie oznacza jednak, że wpłynie to na szybkie zwiększenie zakresu stosowania metody biologicznej, w tym entomofagów.

W Załączniku nr III do Dyrektywy 2009/128/WE w p. 4 czytamy: „Nad metody chemiczne przedkładać należy zrównoważone metody biologiczne, fizyczne i inne metody niechemiczne, jeżeli zapewniają one zadawalającą ochronę przed organizmami szkodliwymi”.

To bardzo ważny zapis, ale wyjątkowo łatwy do niestosowania go, jeżeli brak będzie opracowanych metod biologicznych i innych niechemicznych oraz zachęt do ich stosowania.

Jako kraj jesteśmy w uprzywilejowanej sytuacji. Bogate i zróżnicowane środowisko rolnicze, dobrze przygotowana kadra naukowa i dydaktyczna, ważny początek upowszechnienia wiedzy o organizmach pożytecznych (Tomalak i Sosnowska 2008) dają dobre podstawy do dalszych prac, pod warunkiem stworzenia ku temu odpowiednich warunków.

\section{Literatura / References}

Bereś P.K. 2008. Efekty biologicznego zwalczania omacnicy prosowianki (Ostrinia nubilalis Hbn.) w południowo-wschodniej Polsce. [Effects of biological control of European corn borer (Ostrinia nubilalis Hbn.) in south-eastern Poland]. Prog. Plant Prot./Post. Ochr. Roślin 48 (4): 1281-1284.

Bereś P.K., Lisowicz F. 2005. Przydatność kruszynka (Trichogramma spp.) w ochronie kukurydzy przed omacnica prosowianką (Ostrinia nubilalis Hbn.) w gospodarstwach ekologicznych. [Effectiveness of Trichogramma spp. in maize protection against European corn borer (Ostrinia nubilalis Hbn.) in ecological farms]. Prog. Plant Prot./Post. Ochr. Roślin 45 (1): 47-51.

Dąbrowski Z.T. 2000. Od nauki do praktyki integrowanej ochrony roślin. Ochrona Roślin 8: 3-5.

Dąbrowski Z.T. 2010. Wzbogacanie oporu środowiska jako kierunek rozwoju metod biologicznych. [Enhancement of environmental resistance leading to the development of biological control]. Prog. Plant Prot./Post. Ochr. Roślin 50 (3): 1044-1052.

Filippov N.A. 1989. The present state and future outlook of biological control in the USSR. Acta Entomol. Fennica 53: 11-18.

Flint H.L., van den Bosch R. 1981. Introduction to Pest Managament. Plenum, New York, 240 pp.

Górski P. 1973. Praktyczne wykorzystanie kruszynka zmiennego (Trichogramma evanescens West.) w zwalczaniu pachówki strąkóweczki (Laspeyresia nigricana Steph.) na dużych polach produkcyjnych w latach 1970-1971 na terenie województwa gdańskiego. Zesz. Prob. Post. Nauk Rol. 144: 211-218.

Kadłubowski W. 1957. Wyniki wstępnych badań nad możliwością hodowli kruszynka Trichogramma evanescens Bestw. na biomateriale leśnym. Sylwan 101: 42-54.

Kadłubowski W. 1973. Metoda uwalniania kruszynka i ocena jego skuteczności działania. Zesz. Probl. Post. Nauk Rol. 144: 181-190.

Kot J. 1959. Doświadczenia nad wykorzystaniem kruszynka (Trichogramma evanescens West.) w walce z Plutella maculipensis Curt., Pieris bressicae L. i Pieris rapae L. Ekol. Polska Ser. B. 5: 83-88.

Kot J. 1962. Doświadczenia nad wykorzystaniem kruszynka Trichogramma w walce z owocówką jabłkóweczką (Carpcapsa pomonella L.). Zesz. Prob. Post. Nauk Rol. 35: 157-162.

Korbas M., Mrówczyński M. 2011. Metodyka integrowanej ochrony pszenżyta ozimego i jarego. Inst. Ochr. Roślin - PIB, Poznań, 189 ss.

Lipa J.J., Pruszyński S. 2010. Stan wykorzystania metod biologicznych w ochronie roślin w Polsce i na świecie. [Scale of use of biological methods in plant protection in Poland and in the world]. Prog. Plant Prot./Post. Ochr. Roślin 50 (3): $1033-1043$.

Lipa J.J., Sosnowska D., Pruszyński S. 1998. Advances in biological control of Leptinotarsa decemlineata in Poland. Bull. OEPP/ EPPO Bull. 28: 463-470.

Lisowicz F., Kot J. 1999. Efekty introdukcji kruszynka (Trichogramma spp.) w zwalczaniu omacnicy prosowianki (Ostrinia nubilahis Hbn.) na kukurydzy. [Effectiveness of Trichogramma spp. in controling the European corn borer (Ostrinia nubilahis Hbn.) on maize]. Prog. Plant Prot./Post. Ochr. Roślin 39 (2): 493-495.

Niemczyk E., Bąkowski G. 1973. Ekspertyza dotycząca zastosowań kruszynka w zwalczaniu szkodników sadu. Wydział Nauk Rolniczych i Leśnych, Komitet Ochrony Roślin, 50 ss.

Olszak R.W. 2005. Rola drapieżnych i pasożytniczych stawonogów w redukcji liczebności szkodników sadów. [Role of predatory and parasitoid arthropods in the regulation of orchard pest numbers]. Prog. Plant Prot./Post. Ochr. Roślin 45 (1): 325-335.

Olszak R.W. 2010. Rola parazytoidów błonkoskrzydłych w regulacji liczebności roślinożerców. [The importance of hymenopteran parasitoids in limitation of phytophagous insects]. Prog. Plant Prot./Post. Ochr. Roślin 50 (3): 1095-1102.

Pałosz T., Mrówczyński M., Muśnicki Cz. 1994. Podstawy integrowanej ochrony rzepaku ozimego przed szkodnikami. Materiały 34. Sesji Nauk. Inst. Ochr. Roślin, cz. 1: 111-116.

Portčinski I.A. 1912. Naši boži koronki i ich hozaj stviennoje značenie. Trudy po Entomologi. I. Petersburg, 84 ss.

Pruszyński G. 2007. Ochrona entomofauny pożytecznej w integrowanych technologiach produkcji. [Protection of beneficial entomofauna in integrated plant production]. Prog. Plant Prot./Post. Ochr. Roślin 47 (1): 103-107.

Pruszyński G., Fiedler Ż. 2009. Biedronka azjatycka (Harmonia axyridis Pallas) - rzeczywistość i mity. [The Asian lady beetle (Harmonia axyridis Pallas) - facts and myths]. Prog. Plant Prot./Post. Ochr. Roślin 49 (4): 1966-1971.

Pruszyński S. 1989. 100 lat introdukcji owadów pożytecznych w ochronie roślin. Materiały 29. Sesji Nauk. Inst. Ochr. Roślin, cz. 1: $103-112$. 
Pruszyński S. 1997. Practical application of biological method in plant protection in several coutries of Central - Eastern Europe. p. 9-16. Proc. Symp. „Effectiveness and practical application of biological control in plant protection”. Skierniewice, March 18-19, 1997, $157 \mathrm{pp}$.

Pruszyński S., Dąbrowski Z.T., Hurej M., Nawrot J., Olszak R.W. 2012. Naukowe i praktyczne podstawy zwalczania szkodników w integrowanej ochronie roślin. [Scientific and practical basis for pests control in Integrated Pest Management]. Prog. Plant Prot./Post. Ochr. Roślin 52 (4): 843-848.

Samersow W.F., Triepaszko L.I. 1999. Metodologia opracowywania integrowanych systemów ochrony roślin. [Methodology of scientific description of integrated plant protection systems]. Prog. Plant Prot./Post. Ochr. Roślin 39 (1): 33-36.

Stern V.M., Smith R.F., van den Bosch R., Hagen K.S. 1959. The integrated control concept. Hilgardia 29: 11-16.

Tomalak M. 2010. Rynek biologicznych środków ochrony roślin i przepisy legislacyjne. [Market for biological control agents and their legal regulation]. Prog. Plant Prot./Post. Ochr. Roślin 50 (3): 1053-1068.

Tomalak M., Sosnowska D. 2008. Organizmy pożyteczne w środowisku rolniczym. Inst. Ochr. Roślin - PIB, Poznań, 95 ss.

Twardowski J., Hurej M., Jackowski J. 2009. Wpływ zwiększonego zróżnicowania roślinnego w agrocenozach na populacje organizmów szkodliwych i pożytecznych. [Effects of increased plant diversity in agrocenoses on pest populations and their natural enemies]. Prog. Plant Prot./Post. Ochr. Roślin 49 (3): 1112-1123.

Wiąckowska I. 1987. Studia porównawcze nad biologią i ekologią ważniejszych gatunków kruszynka Trichogramma spp. (Hymenoptera, Trichogrammatidae). Rozprawy Naukowe i Monografie. SGGW, Warszawa, 60 ss.

Wiąckowski S.K. 2006. Biologiczne metody ochrony roślin w Polsce: historia, sukcesy, niepowodzenia, perspektywy. Wydawnictwo Stanisław Więckowski, Kielce, 205 ss.

Wiąckowski S.K., Wiąckowska I., Crumpacer J., Kot J. 1963. Biologiczne zwalczanie owocówki śliwkóweczki Lasperyesia funebrana Tr. (Lepidoptera, Tortricidae) przy wykorzystaniu pasożyta jaj kruszynka Trichogramma cacoeciae March (Hymonoptera, Trichogrammatidae). Cz. II. Wpływ kruszynka na I i II pokolenie szkodnika. Rocz. Nauk Rol. 87: 545-557.

Wiech K., Wnuk A., Wojciechowicz-Żytko E., Jankowska B. 2009. Wpływ infrastruktury ekologicznej na agrofagi i organizmy pożyteczne w uprawach warzyw. [The influence of ecological infrastructure on vegetable pests and beneficial insects]. Prog. Plant Prot./Post. Ochr. Roślin 49 (3): 1124-1132.

Żołnierz R., Hurej M. 2005. Występowanie omacnicy prosowianki (Ostrinia nubilalis Hbn.) na plantacji kukurydzy nasiennej na terenie województwa opolskiego. [Infestation of corn grown for seeds by the European corn borer (Ostrinia nubilalis Hbn.) in Opole province]. Prog. Plant Prot./Post. Ochr. Roślin 45 (2): 1233-1236. 